\title{
Using Geospatial technologies for Sustainable Urban Development
}

\author{
Abdul Raouf* \\ Department of Geomatics and Surveying Engineering Technology, Saskatchewan Polytechnic, Canada
}

Submission: September 10, 2018; Published: September 14, 2018

*Corresponding author: Abdul Raouf, Department of Geomatics and Surveying Engineering Technology, Saskatchewan, Canada,

Email: raoufa@saskpolytech.ca

\section{Opinion}

Urbanization is a natural process, resulting in an everincreasing number of mega sites worldwide. The rate of urbanization has increased from under 30\% in 1950 to over $54 \%$ in 2014 (UN, 2014). It has been estimated by the United Nations that about $80 \%$ of the global population will be living in cities by 2050. Exploding mega cities bring challenges for city planners and local governments. While a growing number of slum areas is a big challenge for expanding cities, reduction of green spaces and infrastructure development in areas prone to natural disasters is perhaps a bigger dilemma. If not planned carefully, these expanding cities cannot be sustainable due to the risks associated with natural disasters such as floods. These natural disasters can cause damage to personal property, public infrastructure, but most importantly, they can result in a serious loss of human lives. The UN has set a sustainability goal for all nations to make cities and human settlements inclusive, safe resilient and sustainable by 2030 [1-3]. Identification of areas prone to natural disasters and imposing development restrictions in these areas is the only solution for the long-term sustainability of expanding cities. Latest geospatial technologies, including remote sensing and geographic information systems (GIS), can be effectively used for the identification and mapping of areas prone to natural disasters. Accuracy of these maps depend upon the use of state-of-the-art geospatial technologies for data acquisition and analysis. These technologies may include Light Detection and Ranging (LiDAR), high resolution aerial photographs, Global Navigational Satellite Systems (GNSS), and Geographic Information System (GIS). Such maps must be updated on a regular basis to help city administrators make informed decisions when re-zoning or developing new residential zones. These maps should also be available to the public so that their safety is not compromised through the commercialization of urban development. This paper will summarize the use of latest geospatial technologies for sustainable urban development through the identification flood prone areas.

\section{Flooded Cities}

The ecology of Earth and its environment is a combination of highly interrelated systems. Changes in one system can cause severe, and sometimes irreversible, changes in the other. Increasing population, over utilization of resources, increasing emission of greenhouse gasses, and the ever-expanding human ecological footprint are some of the causes of global warming. Slowing jet streams, unusual and severe weather systems, melting glaciers and rising sea levels at a faster speed are some of the profound environmental effects of global warming. Heavy rain over a short period of time causing flash flooding is another common consequence in many parts of the world. Unfortunately, such events are becoming even more severe and frequent with the passage of time [4].

Information about flooded cities is routinely broadcasted over news media. It is safe to say that floods are one of the costliest natural disasters of the current age. For example, it is estimated that Canada spends $\$ 600$ million annually for cover flood related damages. The National Oceanic and Atmospheric Administration (NOAA) ranks Hurricane Harvey as the costliest natural disaster worldwide due to the unprecedented amounts of rainfall over Houston in August of 2017. Financial damages caused by Hurricane Harvey exceeded US \$125 billion. NOAA further reported that the frequency of weather related events, each costing over a billion dollars, has increased in last five years. The USA has experienced 17 such events in 2017. The population living in areas prone to natural disasters like flood plains is just one of the factors behind the increase in weather related damages. Sadly, the majority of people are not informed that they are living in a designated flood plain. A national survey conducted by the University of Waterloo in Canada, revealed that out of 2,300 people surveyed, only 138 knew that their property was in a vulnerable area $[5,6]$. The residents of vulnerable areas can only play their part in flood damage reduction if they are aware of the vulnerability of their residence. It is believed that the unavailability of updated and accurate maps indicating areas prone to natural disasters to the public has caused this lack of 
awareness. There is an urgent need of an awareness campaign through information dissemination to resolve this issue.

\section{Geo Spatial Technologies}

The majority of the existing flood zone maps are based on historical flood recurrence data. Typically, an area having a $0.2 \%$ ( 1 in 500 years) probability of flooding is classified as a flood plain. It is also referred to as 1:500 in mapping. However, different countries and even municipal jurisdictions within the same country may use different values of historical flood recurrence data. Flood maps with $0.01 \%-1.0 \%$ ( 1 in 1,000 years - 1 in 100 years) are commonly seen throughout the world. This therefore shows inconsistencies within flood zone mapping process. Inaccuracies associated with historical flood data due to outdated data collection and mapping techniques are difficult to determine but can also raise a question about the accuracies of the existing flood zone maps. In addition to that, existing flood zone maps based on historical data are outdated as they do not account for climate change [7-9]. The Federal Emergency Management Agency (FEMA) of the USA reported in 2004 that approximately $70 \%$ of USA flood zone maps were reported to be based on outdated data and were more than 10 years old. Conservation Ontario reported in 2017 that up to $78 \%$ of the provincial floodplain maps were outdated [10].

The use of latest geospatial technologies is perhaps the only solution for the regular updates of flood zone maps. These technologies use digital elevation model (DEM) to extract elevation information of an area to determine flood zone maps. Base Flood Elevation (BFE) is a reference surface elevation beyond which water levels are considered as flooded water, can effectively be used for flood zone mapping. However, establishing $\mathrm{BFE}$ is a challenging process as it is highly dependent on topography of the area. It can simply be an elevation of river edges for narrow and sharply carved river channels or elevation of floodway boundaries and extent of base flood events. High resolution aerial photographs or satellite images can be used to extract river edges, floodway boundaries or extent of base flood events. A predefined safe elevation margin should be added to BFE to classify an area as a floodplain [11]. This safe margin should also accommodate errors associated with the identification of BFE and elevation information derived from DEM. NASA is generously helping the international community to update their flood zone maps on regular basis and has recently released an accurate DEMs generated from Shuttle Radar Topography Mission Global 1 arc data $(\approx 30 \mathrm{~m}$ spatial resolution). Light Detection and Ranging (LiDAR) data can also be used to derive more accurate DEMs, resulting in better quality flood zone maps. Several studies have been published to support the use of LiDAR data for flood zone mapping. Several worldwide agencies have therefore realized the importance of accurate flood zone maps and have already started updating their outdated maps. However, regular updating of flood zone maps is a continuous process as flood zones can change because of several natural and manmade reasons including global warming and unplanned/coordinated infrastructure development.

\section{Conclusion}

Availability of high resolution satellite images and accurate DEMs has made it possible to create or update flood zone maps on a regular basis. The accuracy of floodplain maps depends on the accuracy of the DEM and accurate identification of BFE. Latest geospatial technologies like remote sensing, global navigation satellite system (GNSS) and geographic systems (GIS) can effectively be used for this purpose. These maps should be made available to the general public so that they can make informed decisions when purchasing a property or choosing to live in vulnerable areas. In the end, city planners and local governments should restrict infrastructure development within floodplains.

\section{References}

1. Adriano L (2017) Three-quarters of Ontario's floodplain maps are outdated: Experts.

2. GAO (2004) Flood Map Modernization. United States General Accounting Office.

3. Merwade V, Olivera F, Arabi M, Edleman S (2008) Uncertainty in Flood Inundation Mapping: Current Issues and Future Directions. Journal of Hydrologic Engineering 13(7): 608-620.

\section{NASA (2017) EARTHDATA.}

5. Peng Y, Raouf A, Almas M (2018) An analytical comparison of flood zones derived from point cloud LiDAR data and historical flood data: A case study of Moose Jaw, Saskatchewan Canada.

6. Smith AB (2018) 2017 US billion-dollar weather and climate disasters: A historic year in context.

7. Thistlethwaite J, Henstra D, Peddle S, Scott D (2017) Canadian Voices on Changing Flood Risk: Findings from a National Survey. Waterloo: Interdisciplinary Center on Climate Change, University of Waterloo, Canada.

8. UN (2014) World Urbanization Prospects: The 2014 Revision, Highlights. New York: Department of Economic and Social Affairs.

9. UNA (2018) The Sustainable Development Goals 2015 - 2030. United Nation Association of Greater Philadelphia.

10. van de Sande B, Lansen J, Hoyng C (2012) Sensitivity of Coastal Flood Risk Assessments to Digital Elevation Models. Water 4: 568-579.

11. Webster TL (2010) Flood Risk Mapping Using LiDAR for Annapolis Royal, Nova Scotia, Canada. Remote Sensing 2: 2060-2082. 
is work is licensed under Creative Commons Attribution 4.0 License

DOI: 10.19080/IJESNR.2018.14.555884
Your next submission with Juniper Publishers will reach you the below assets

- Quality Editorial service

- Swift Peer Review

- Reprints availability

- E-prints Service

- Manuscript Podcast for convenient understanding

- Global attainment for your research

- Manuscript accessibility in different formats ( Pdf, E-pub, Full Text, Audio)

- Unceasing customer service

Track the below URL for one-step submission https://juniperpublishers.com/online-submission.php 